\title{
PENERAPAN ACTIVE LEARNING STRATEGI KONSTRUKTIVISME PADA PEMBELAJARAN ALQUR'AN HADIS DI MADRASAH TSANAWIYAH NEGERI 2 LABUHANBATU
}

\author{
Siti Aisah \\ Mahasiswa Pascasarjana FITK UINSU
}

\begin{abstract}
Abstrac
This study aims to answer the problems posed, namely how:(1) teacher preparation for the Hadith in applying the constructivism learning strategies? (2) the application of the steps of the Hadith Al-Qur'an teacher applies the constructivism learning strategies? (3) the involvement of students in the learning of the Qur'an Hadith using constructnivism? (4) constraints or barriers to the Qur'anic Hadith teacher in applying constructivism, andn (5) the effectiveness and learning outcomes of the AlQur'an Hadith and the application of the constructivism learning strategies?. The subjects of this study were the two Qur'anic Hadith teachers who worked over five years. Data collection techniques are carried out by observation, interviews, and document studies. The data analysis technique uses three stages, data reduction, data display, and conclusion as recommended by Miles and Huberman. The results, First, the teacher has made preparations before conducting teaching activities in the form of preparation of syllabus and Learning Implementation Plans that have been previously validated (checked) by the principal. Second, the implementation of constructivism learning strategis in learning has been carried out, but from the four steps of the constructivism learning strategies it has not been fully implemented properly. Third, student involvement in learning tends to be active and the learning conditions are pleasant. Fourth, the obstacles or obstacles encountered by the teacher relate to the circumstances and completeness of learning resources and media. Fifth, the effectiveness and student learning outcomes increase which can be seen from the acquisition of their mastery learning value.
\end{abstract}

Keyword: Strategi Konstruktivisme, Pembelajaran Al-Quran Hadis

\section{PENDAHULUAN}

Siswa sebagai subjek belajar yang aktif memiliki potensi untuk membangun pengetahuannya sendiri. Belajar melalui kegiatan kelompok, seperti kerja kelompok, berdiskusi, saling menerima dan membagi informasi merupakan salah satu ciri dari pelaksanaan pembelajaran dengan pendekatan kontekstual. Paradigma pembelajaran merupakan cara pandang dan anggapan guru kepada siswa yang belajar bahwa mereka adalah organisme dinamik yang perlu dikembangkan 
secara terus menerus. Paradigma pembelajaran yang benar untuk dipraktikkan guru adalah menyediakan kondisi yang kondusif bagi siswa untuk belajar yang memungkinkan mereka dapat beratisipasi aktif dalam kegiatan tersebut dengan menyediakan waktu yang cukup untuk melakukan analisis berpikir. Karena itu, anggapan yang menyatakan bahwa kelas sebaiknya didominasi oleh guru (teacher-dominated class), selayaknya diganti dengan kelas yang didominasi oleh siswa (studentdominated class).

Perubahan paradigma tersebut menghendaki penggunaan strategi dan metode pembelajaran yang variatif. Penetapan dan penggunaan suatu strategi pembelajaran harus dipertimbangkan secara matang agar memiliki kesesuaian dengan materi yang akan diajarkan, siswa yang dihadapi dan lain sebagainya. Salah satu strategi/metode yang dapat meningkatkan keterlibatan siswa adalah konstruktivisme. Konstruktivisme merupakan salah satu aliran pendidikan yang berkembang dalam psikologi pembelajaran.

Pembelajaran kontekstual adalah strategi atau pendekatan yang melibatkan siswa dalam proses pembelajaran secara optimal. Guru mendorong siswa untuk mempelajari materi pelajaran sesuai dengan pokok bahasan yang akan dipelajarinya. Belajar dalam pembelajaran kontekstual bukan hanya mendengarkan dan mencatat apa yang disajikan guru, tapi merupakan proses membangun (construct) pengalaman secara langsung. Melalui itu diharapkan perkembangan siswa terjadi secara utuh, baik aspek kognitif, afektif, maupun psikomotor. Siswa diharapkan dapat menemukan sendiri materi yang akan dipelajarinya. Karena pembelajaran kontekstual (contextual teaching and learning) merupakan suatu strategi pembelajaran yang menekankan kepada proses keterlibatan siswa secara penuh untuk dapat menemukan materi yang dipelajari dan menghubungkannya dengan situasi kehidupan nyata sehingga mendorong siswa untuk dapat menerapkannya dalam kehidupan mereka (Sanjaya, 2010:255). Konstruktivisme memiliki pandangan mengenai belajar. Konstruktivisme merupakan suatu pendekatan pembelajaran yang menekankan agar individu secara aktif membangun pemahaman dan pengetahuannya sendiri. Proses menyusun pengetahuan yang dilakukan berdasarkan pada pengalaman-pengalaman yang dimiliki siswa tersebut. Proses pembelajaran dan interaksi yang terjadi hanya untuk menguatkan (validasi) atas pengetahuan dan pemahaman yang telah disusun tersebut untuk dipergunakan dalam kehidupannya. 


\section{KAJIAN TEORETIS}

Silberman (2013:12), pendekatan active learning merupakan sebuah kesatuan sumber kumpulan strategi-strategi pembelajaran yang komprehensif, meliputi berbagai cara untuk membuat siswa menjadi aktif. Nurdin dan Usman (2009:177), menyatakan active learning merupakan suatu proses belajar mengajar yang aktif dan dinamis. Dalam proses ini siswa mengalami keterlibatan intelektual-emosional disamping keterlibatan fisiknya.

Rohani (2009:61), keterlibatan siswa secara aktif dalam proses pembelajaran yang diharapkan adalah keterlibatan secara mental (intelektual dan emosional). Sehingga siswa benar benar berperan serta dan berpartisipasi aktif dalam proses pembelajaran dengan menempatkan kedudukan siswa sebagai subyek, dan sebagai pihak yang penting dan merupakan inti dalam kegiatan belajar mengajar. Pada hakikatnya konsep ini adalah untuk mengembangkan keaktifan proses pembelajaran. Jadi dalam active learning tampak jelas adanya guru aktif mengajar di satu pihak dan siswa aktif belajar di lain pihak.

Strategi pembelajaran yang memungkinkan siswa dapat melakukan aktivitas belajarnya dan mengembangkan kemampuan siswa adalah konstruktivisme. Konstruktivisme merupakan suatu pendekatan pembelajaran yang menekankan agar individu secara aktif membangun (to construct) pemahaman dan pengetahuannya sendiri. Proses menyusun pengetahuan yang dilakukan berdasarkan pada pengalaman-pengalaman yang dimiliki dan dialami siswa itu sendiri. Proses pembelajaran dan interaksi yang terjadi hanya untuk menguatkan (memvalidisi) atas pengetahuan dan pemahaman yang telah disusun tersebut untuk agar dipergunakan dalam kehidupannya (Fosnot eds, 2005: 3).

Dengan menerapkan konstruktivisme ini guru dituntut mampu menyusun dan melaksanakan suatu kegiatan pembelajaran yang dapat memfasilitasi siswa agar aktif membangun pengetahuannya sendiri. Menurut paham kontruktivisme, keberhasilan belajar tidak hanya bergantung pada lingkungan atau kondisi belajar, tetapi juga pada pengetahuan awal siswa dan melibatkan pembentukan "makna" oleh mereka itu sendiri berdasarkan apa yang telah mereka lakukan, lihat, dan dengar.

Duffy \& Cuningham sebagaimana dikutip Jonnassen (2006:170) menggambarkan konstruktivisme sebagai berikut: konstruktivisme merupakan cara yang dianggap modern yang berhubungan dengan bagaimana seseorang membangun pengetahuannya dengan memberikan 
makna kepada pengalaman nyata berdasarkan pengetahuan awal, struktur mental, pengalaman, dan kepercayaan. Hal itu didasarkan pada asumsi bahwa sumber dari pemahaman seseorang mengenai lingkungan adalah pikiran seseorang tersebut. Beberapa ahli konstruktivisme mempercayai bahwa tidak ada makna yang bebas dari aktivitas mental manusia.

\section{METODOLOGI PENELITIAN}

Penelitian ini dilaksanakan di MTs. Negeri 2 Labuhanbatu. Penelitian ini menggunakan paradigma kualitatif sebab peneliti ingin mendeskripsikan bagaimana sebenarnya pelaksanaan strategi pembelajaran active learning pada mata pelajaran Alqur'an Hadis.

Seluruh peristiwa di MTs. Negeri 2 Labuhanbatu merupakan latar alamiah (natural setting) yang ditempatkan sebagai sumber data. Peneliti bertindak sebagai instrumen kunci, mengamati secara berulang-ulang dan mencatat data secara teliti, sistematis dan menganalisis secara induktif. Setiap perilaku informan baik pimpinan maupun staf dan personil lainnya (constituent) dideskripsikan sehingga ditemukan makna dari suatu temuan. Pemahaman terhadap makna perilaku aktor di MTs. Negeri 2 Labuhanbatu dalam penerapan strategi pembelajaran konstruktivisme yang dilaksanakan guru-guru dalam pembelajaran memerlukan keterlibatan langsung peneliti. Demikian pula interaksi dan keterlibatan siswa dalam proses pembelajaran dilakukan dalam objek yang alami, memungkinkan penelitian ini dilakukan dalam pendekatan kualitatif.

Pengumpulan data pada penelitian ini diperoleh dengan teknik: (1) observasi (2) wawancaram dan melakukan pengkajian dokumen (document study) yang dimiliki madrasah. Pada mulanya data yang didapat dari informan sesuai dari sudut pandang informan/responden (emic). Selanjutnya data yang sudah dianalisis berdasarkan dari sudut pandang peneliti (etic).

Analisis data kualitatif dengan menggunakan model interaktif dari Miles dan Huberman yang diterjemahkan Tjetjep Rohendi Rohidi (1992) yang terdiri dari: (a) reduksi data (b) penyajian data, dan (c) kesimpulan, di mana prosesnya berlangsung secara sirkuler selama penelitian berlangsung.

\section{HASIL PENELITIAN DAN PEMBAHASAN}

Temuan pertama dalam penelitian ini adalah berkaitan dengan persiapan guru dalam melaksanakan pembelajaran. Berdasarkan hasil 
analisis data diperoleh bahwa semua guru telah melakukan persiapan dan perencanaan pembelajaran yang dilakukan sebelum kegiatan mengajar dimulai. Bentuk persiapan-persiapan yang dilakukan adalah membuar RPP dan perangkat pembelajaran yang sebelumnya harus divalidasi oleh Kepala Madrasah. Hal ini dimaksudkan untuk menyesuaikan antara apa yang direncanakan dengan apa yang akan dilakukan guru di dalam kelas. Praktik pembelajaran yang dilakukan secara terencana dan persiapan yang matang akan memberi peluang terhadap keberhasilan siswa dalam belajar. Tujuan belajar akan menjadi lebih terarah, karena telah dirumuskan terlebih dahulu. Sesuatu yang bukan menjadi tujuan belajar, pasti tidak akan dilakukan oleh guru dan siswa.

Di dalam Undang-undang Sistem pendidikan Nasional Nomor 20 tahun 2003 dinyatakan bahwa pembelajaran adalah proses interaksi peserta didik dengan guru dan sumber belajar pada suatu lingkungan belajar. Pembelajaran sebagai interaksi antara guru dengan satu atau lebih siswa untuk belajar, direncanakan sebelumnya dalam rangka untuk menumbuhkembangkan pengetahuan, keterampilan, dan pengalaman belajar kepada siswa. Makna pembelajaran secara lebih luas sebagai suatu kombinasi yang tersusun meliputi unsur-unsur manusiawi, material, fasilitas, perlengkapan, dan prosedur yang saling mempengaruhi untuk mencapai tujuan pembelajaran.

Dalam konteks pembelajaran, perencanaan dapat diartikan sebagai suatu proses penyusunan materi pembelajaran, penggunaan media pengajaran, penggunaan atau pendekatan metode, dan penilaian, menentukan alokasi waktu untuk mencapai tujuan tertentu. Perencanaan pembelajaran adalah proses pengambilan keputusan hasil berpikir secara rasional tentang sasaran dan tujuan pembelajaran tertentu, yakni perubahan perilaku serta rangkaian kegiatan yang harus dilaksanakan sebagai upaya pencapaian tujuan tersebut dengan memanfaatkan segala potensi dan sumber belajar yang ada (Sanjaya, 2010).

Temuan kedua, berdasarkan hasil analisis data yang dilakukan tentang langkah-langkah penerapan konstruktivisme dalam di MTs. Negeri 2 Labuhabatu dapat dikemukakan bahwa dari keempat langkah konstruktivisme, yaitu invitasi (mengundang), eksplorasi (menjelajahi), eksplanasi (menjelaskan), dan refleksi (menarik kesimpulan) belum dilakukan guru secara maksimal. Langkah ketiga yakni eksplanasi (menjelaskan) lebih banyak dilakukan guru daripada langkah-langkah yang lain. Ini berarti bahwa kegiatan pembelajaran lebih banyak 
didominasi guru, sedangkan siswa lebih diposisikan sebagai objek yang banyak menerima.

Meskipun diakui bahwa guru -guru telah melakukan upaya-upaya yang terkait dengan pelaksanaan strategi pembelajaran untuk mengaktifikan siswa dalam belajar. Namun sayangnya, upaya yang dilakukan guru adalah kurang memberikan kesempatan/waktu yang cukup kepada siswa untuk melakukan aktivitas/kegiatan belajarnya secara optimal. Model pembelajaran yang digunakan guru untuk hal tersebut adalah dengan menerapkan pembelajaran aktif (active learning). Salah satu strategi pembelajaran yang memungkinkan siswa dapat melakukan aktivitas belajarnya adalah dengan menerapkan konstruktivisme. Konstruktivisme merupakan suatu pendekatan pembelajaran yang menekankan agar individu secara aktif membangun (to construct) pemahaman dan pengetahuannya sendiri. Proses menyusun pengetahuan yang dilakukan berdasarkan pada pengalaman-pengalaman yang dimiliki dan dialami siswa itu sendiri. Proses pembelajaran dan interaksi yang terjadi hanya untuk menguatkan (memvalidisi) atas pengetahuan dan pemahaman yang telah disusun tersebut untuk agar dipergunakan dalam kehidupannya.

Dengan menerapkan strategi konstruktivisme ini guru dituntut mampu menyusun dan melaksanakan suatu kegiatan pembelajaran yang dapat memfasilitasi siswa agar aktif membangun pengetahuannya sendiri. Menurut paham kontruktivisme, keberhasilan belajar tidak hanya bergantung pada lingkungan atau kondisi belajar, tetapi juga pada pengetahuan awal siswa dan melibatkan pembentukan "makna" oleh mereka itu sendiri berdasarkan apa yang telah mereka lakukan, lihat, dan dengar.

Sebagai upaya melatih siswa bagaimana menemukan pengetahuan baru, guru sebaiknya memperhatikan perkembangan struktur kognitif yang ada pada mereka. Pada proses belajar mengajar, guru tidak lagi hanya mentransfer ilmu pengetahuan, tetapi mereka sendiri yang harus membangun pengetahuannya (knowledge is constructed by human).

Pembelajaran Alqur'an Hadis dapat diterapkan dalam proses pembelajaran di kelas menggunakan konstruktivisme harus melibatkan banyak campur tangan (intervensi) guru tetapi juga harus memberikan waktu yang cukup kepada siswa untuk mengeksplorasi dunia mereka dan menemukan pengetahuan. Bagaimana pendidikan dapat merangsang siswa agar mau belajar dengan kesadaran yang muncul dari dalam dirinya sendiri. Campur tangan (intervensi) itu yang besar dari guru 
didasarkan kepada kenyataan bahwa: (1) setiap siswa memiliki perbedaan atau individual differences antara satu dengan yang lainnya, (2) penyebaran informasi terjadi secara sangat cepat sehingga penyampaian materi pembelajaran yang dilakukan di dalam kelas semata-mata tidak didasarkan kepada batasan-batasan yang tertulis di dalam kurikulum, (3) pembelajaran yang mengedepankan nilai-nilai humanisme di mana setiap siswa harus ditempatkan sebagai orang yang memiliki keinginan dan harapan untuk diwujudkan secara aktual, dan (4) dalam rangka mencapai tujuan pendidikan nasional sebagaimana yang tertera di dalam UndangUndang dinyatakan sebagai berikut: "Mengembangkan kemampuan dan membentuk watak serta peradaban bangsa yang bermartabat dalam rangka mencerdaskan kehidupan bangsa, bertujuan untuk berkembangnya potensi siswa agar menjadi manusia yang beriman dan bertaqwa kepada Tuhan Yang Maha Esa, berakhlaq mulia, sehat, berilmu, cakap, kreatif, mandiri, dan menjadi warga negara yang demokratis serta bertanggung jawab" (Undang-Undang Nomor 20 Tahun 2003 tentang Sistem Pendidikan Nasional).

Salah satu ciri yang menonjol dalam pembelajaran model ini adalah bahwa para siswa dihadapkan dengan dunia nyata dan dengan dunia nyata yang dihadapinya tersebut para siswa tersebut mampu berbuat dengan yang sebenarnya. Model atau paradigma pembelajaran yang ditepat dilakukan guru memiliki 10 karakteristik pokok, sebagai berikut: (1) berpusat pada siswa, (2) belajar dengan melakukan, (3) mengembangkan kemampuan sosial, (4) mengembangkan keingintahuan, imajinasi, dan fitrah bertuhan, (5) mengembangkan keterampilan memecahkan masalah, (6) mengembangkan kreativitas siswa, (7) mengembangkan kemampuan menggunakan ilmu dan teknologi, (8) menumbuhkan kesadaran sebagai warga negara yang baik, (9) belajar sepanjang hayat, dan (10) perpaduan kompetisi, kerjasama dan solidaritas.

Temua ketiga dalam penelitian ini adalah berkaitan dengan keterlibatan siswa dalam pembelajaran. Pilosofis penggunaan pembelajaran aktif (active learning) adalah mengoptimalkan siswa dalam kegiatan belajar agar dapat terllibat secara pisik dan menta. Keterlibatan mental siswa dalam belajar lebih penting daripada pisik. Namun akan lebih baik apabila antara pisik dan mental keduanya sama-sama terlibat dalam aktivitas belajar. Keterlibatan (engagment) adalah salah satu dasar yang menyebabkan terbentuknya kemampuan berpikir siswa. Walls dalam Bulger, et.al. (2002:1), merekomendasikan 4 aspek yang mendukung terlaksana pembelajaran yang mendukung terbentuknya kemampuan 
berpikir siswa, yaitu: (1) outcomes, (2) clarity, (3) engagment, dan (4) enthusiasm". Outcomes (hasil) merupakan sasaran atau tujuan yang akan dicapai siswa. Semakin jelas tujuan yang akan dicapai siswa, maka akan semakin termotivasi juga siswa dalam mencapainya. Karena tujuan dapat mengarahkan siswa, harus melakukan aktivitas apa dan dengan cara bagaimana.

Clarity (kejelasan) menjadi kunci terwujudnya pembelajaran efektif. Kejelasan berkaitan dengan cara penyampaian dan apa yang disampaikan (konten pelajaran). Dengan demikian, konten pelajaran juga perlu didukung dengan penggunaan metode strategi pembelajaran yang sesuai. Memposisikan siswa dalam proses pembelajaran sebagai subjek yang aktif dan dinamis dengan lebih memberikan peluang bagi mereka untuk memahami materi pelajaran yang disampaikan merupakan cara yang terbaik dilakukan guru. Bulger et.al, (2002:1), menyarankan agar guru menempatkan siswa dalam proses pembelajaran sebagai organisme/individu yang berkembang dan dikembangkan potensinya (scaffolding)". Secara sederhana scaffolding berarti pemerkahan.

Dengan teori scaffolding ini mempertegas bahwa siswa merupakan organisme makluk hidup dan berkembang sesuai dengan perlakuan yang diterimanya. Jika perlakuan yang diterima itu tepat, maka memungkinkan kemampuan siswa akan berkembang secara optimal, demikian sebaliknya. Prinsip utama dari engagement (keterlibatan) ini adalah siswa belajar dengan melakukan (learn by doing) (Burger, et.al, 2002:1). Dalam hal ini, fungsi guru sebagai penyampai (deliverer) informasi dan siswa sebagai penerima (receiver) menjadi dua komponen yang tak dapat dipisahkan. Akan tetapi fungsi dan peranan guru dituntut dapat menciptakan kondisi yang dinamis, menciptakan lingkungan pembelajaran yang dapat merangsang berpikir siswa, dan memberikan kesempatan kepada semua siswa untuk mempraktikkan konsep/masalah-masalah yang dipelajari. Penerapannya dapat dilakukan dengan cara guru membatasi waktu menjelaskan materi pembelajaran secara verbal, kemudian memberikan kesempatan kepada siswa untuk mempraktikkannya (Bulger, et.al, 2002:1).

Enthusiasm berarti semangat yang ditunjukkan siswa dalam belajar. Guru dapat membangun enthusiasm ini dengan cara membangun lingkungan belajar yang positif dengan cara menunjukkan manfaat dari materi yang akan dipelajari, menguatkan partisipasi siswa selama proses pembelajaran, dan mengaktifkan semua siswa (Bulger, et.al, 2002:1). 
Temuan keempat dalam penelitian ini adalah berkaitan dengan kendala atau hambatan dalam penerapan konstruktivisme. Konstruktivisme sebagai salah satu model pembelajaran aktif memerlukan dukungan baik dari guru yang melaksanakan proses pembelajaran maupun sumber dan media pembelajaran. Guru sebagai orang terdepan dalam proses pembelajaran memiliki peran strategis yang tak tergantikan oleh apa dan siapa pun. Karena itu, guru wajib melengkapi dirinya dengan berbagai kemampuan untuk melaksanakan pembelajaran secara efektif dan efisien. Salah satu kemampuan guru yang sangat penting adalah kemampuan menetapkan dan menggunakan strategi pembelajaran, termasuk konstruktivisme ini.

Selain itu kendala atau hambatan yang dihadapi dalam penerapan konstruktivisme ini adalah faktor media. Media yang digunakan guru di MTs. Negeri 2 Labuhanbatu dapat dikatakan variatif. Pada setiap ruang kelas sudah terpasang satu unit infocus, sehingga dalam proses pembelajaran guru hanya menampilkan materi dalam bentuk slide. Setiap tampilan slide dijelaskan dengan seksama, dan kepada siswa diminta memberikan respons berupa tanggapan. Namun media-media pembelajaran yang ada tampaknya kurang didapat dimanfaatkan secara optimal.

Dalam proses pembelajaran, penggunaan teknologi pembelajaran masih jarang dilakukan, karenanya penyajian materi pelajaran tidak menarik. Salah satu fungsi media adalah dapat membangkitkan keinginan dan minat baru. Dengan menggunakan media, wawasan dan pengalaman siswa akan semakin luas, persepsi semakin tajam, dan konsep-konsep dengan sendirinya menjadi semakin lengkap. Ini menyebabkan keinginan dan minat baru untuk belajar selalu timbul.

Dengan penggunaan alat/media dalam suatu pembelajaran dapat merangsang pikiran, perasaan dan kemauan siswa sehingga dapat mendorong terjadinya kegiatan belajar pada dirinya. Penggunaan media secara kreatif dapat memungkinkan siswa untuk belajar lebih banyak, dapat memahami apa yang dipelajarinya dengan baik dan meningkatkan kemampuan mereka sesuai dengan tujuan yang ingin dicapai.

Romizowski (2001: 338), mendefinisikan media sebagai: As the carriers of messages, from some transmitting source (which may be a human being or an inanimate object), to the receiver of the message (which in our case is the learner). Defenisi tersebut mengandung pengertian bahwa media adalah sesuatu yang bisa menyampaikan pesan dari berbagai sumber (bisa berupa manusia atau bukan manusia) kepada penerima pesan (dalam konteks 
pembelajaran dinamakan siswa). Oleh karena itu, berdasarkan pengertian tersebut pengertian media adalah semua alat (berupa manusia ataupun bukan manusia) yang bisa menyalurkan pesan dari guru kepada siswa. Sebagai konsekwensinya adalah dalam suatu kegiatan pembelajaran, guru dapat menggunakan semua peralatan yang memungkinkan pesan (materi pembelajaran) dapat disampaikan kepada siswa secara efektif dan efisien, termasuk dirinya sendiri. Perlu digaris bawahi penggunaan berbagai alat dalam kegiatan pembelajaran harus disesuaikan dengan berbagai pertimbangan, antara lain: (1) tujuan yang ingin dicapai, (2) karakteristik siswa, (3) sifat atau jenis materi yang akan disampaikan, (4) ketersedian alat yang akan digunakan, (5) ketepatan atau akurasi, serta mutu teknis dari alat yang akan digunakan tersebut.

Keahlian guru menggunakan teknologi pembelajaran dapat menarik perhatian dan minat siswa dalam belajar karena beberapa hal: (1) berupaya menampilkan/menyajikan pesan semenarik mungkin. (2) penyampaian materi menggunakan slide dalam bentuk power point, dan (3) selain menarik, media perlu dirancang dengan jelas namun memiliki kesederhana sehingga dapat sesuai dengan tujuan pembelajaran.

Temuan kelima dalam penelitian ini adalah berkaitan dengan efektivitas dan hasil yang dicapai siswa. Dalam beberapa penelitian tentang konstruktivisme mennjukkan bahwa ada pengaruh yang signifikan dengan efektivitas dan perolehan hasil belajar siswa. Penelitian yang dilakukan Bilgin, Senocak, dan Sozbilir (2008), menunjukkan bahwa siswa yang diperlakukan dengan konstruktivisme memiliki kemampuan yang lebih baik dalam hal menemukan masalah.

Hasil penelitian yang dilakukan Strobel \& Van Barneveld (2009) menyarankan penerapan konstruktivisme dalam pembelajaran karena: (1) Mampu meningkatkan dan menyimpan pengetahuan dalam kurun waktu yang lama, (2) mampu meningkatkan keterampilan menyelesaikan masalah (Kanet \& Barut, 2009). (3) mampu meningkatkan kemampuan analisis dan berargumentasi dengan mengajukan alasan-alasan rasional (Michel, Bishoff, \& Jakobs, 2002), (4) Mampu meningkatkan keterampilan interpersonal (Kumar \& Natarajan, 2007). Interpersonal adalah salah satu bentuk komunikasi, yang melibatkan orang lain. Dalam konteks pembelajaran, komunikasi interpersonal dapat terjadi antara satu siswa dengan siswa lain, karena dalam konstruktivisme menghendaki adanya kerja sama dalam satu kelompok (grup) untuk mengkaji masalah yang diberikan guru, (5) Mampu meningkatkan keterampilan belajar mengarahkan diri sendiri (Thomas \& Chan, 2002). Di dalam problem based learning, siswa 
dilatih untuk melakukan penyelidikan berbasis individual dalam suatu kelompok. Hasil temuan penelitian ini diperkuat oleh Gijbels, Dochy, Van den Bosch, \& Sergers dalam Wynn Sr, Mosholder \& Larsen (2014:5), menyatakan bahwa pembelajaran dengan menggunakan konstruktivisme akan baik atau lebih baik karena siswa belajar bersama-sama dengan teman-teman lainnya dalam satu kelompok.

Sehubungan dengan temuan penelitiaan ini maka beberapa rekomendasi yang dapat disampaikan adalah: (1) Kepada Kepala MTs. Negeri 2 Labuhanbatu agar melakukan supervisi akademik secara intensif dalam rangka melakukan bimbingan kepada para guru agar memiliki dokumen pembelajaran (silabus dan RPP) yang tepat serta mampu menerapkannya dalam proses pembelajaran. Kepada Kepala MTs. Negeri 2 Labuhanbatu disarankan untuk membuat beberapa kebijakan yang berhubungan dengan: persiapan-persiapan guru sebelum melakukan aktivitas mengajar, penerapan pembelajaran aktif (active learning) yang memberikan kesempatan dan peluang kepada siswa untuk berparisipasi dalam proses pembelajaran, (2) Kepada setiap guru untuk dapat meningkatkan kemampuan menerapkan strategi/model pembelajaran sebagai upaya untuk meningkatkan efektivitas pembelajaran yang berujung pada pencapaian hasil belajar siswa secara optimal, dalam setiap proses pembelajaran sebaiknya selalu menggunakan media tepat untuk membantu siswa memahami materi yang disampaikan guru. Dengan bantuan media yang tepat, maka siswa akan mudah menyerap materi yang disampaikan guru. Kepada setiap guru agar menerapkan berbagai jenis penilaian yang sesuai tujuan belajar, karakteristik siswa serta jenis materi yang dipelajari untuk mengetahui efektivitas dan hasil belajar siswa. Dalam rangka meningkatkan kualitas pembelajaran yang berbasis kompetensi siswa, Kepala Madrasah MTs. Negeri 2 Labuhanbatu perlu memberikan kesempatan kepada para guru untuk melanjutkan pendidikan jenjang S2 bahkan S3, dan mengikut sertakan guru dalam acara seminar, diskusi, penelitian, workshop, dan lain-lain agar pengetahuan para guru dalam hal penerapan pembelajaran aktif ini menjadi lebih baik. 


\section{DAFTAR PUSTAKA}

Afrizal. (2016). Metode Penelitian Kualitatif. Jakarta: Raja Grafindo Persada.

Fosnot, Catherine Twomey. (2006). Contructivism: Theory, Perspectives, and Practice, 2nd Edition. New York: Teachers College.

Johnson, Elaine. B. (2002). Contextual Teaching and Learning: What It Is and Why It's Here to Stay. California: Corwin Press, Inc. A Sage Publications Company.

Jonassen, David ed. (2006). Handbook of Research for Educational Communications and Technology, a Project of The Assosiciation for Educational Communications and Technology. New York: Prentice Hall International.

Moleong, Lexy J. (2016). Metodologi Penelitian Kualitatif. Bandung: Remaja Rosdakarya.

Romizowski, Alexander J.( 2001). Designing Instructional System: Decision Making In Course Planning And Curriculum Design, New-York: Nicholas Publishing Company.

Rusman. (2011). Model-Model Pembelajaran: Mengembangkan Profesional Guru Cetakan keempat. Jakarta: Raja Grafindo Persada.

Sanjaya, Wina. (2010). Strategi Pembelajaran Berorientasi Standar Proses Pendidikan. Cetakan kesepuluh. Jakarta: Prenada Media Group.

Silberman, Melvin L. (2013). Active Learning. Bandung: Nusa Media.

Sugiyono. (2016). Metode Penelitian Kuantitatif, Kualitatif dan $R \mathcal{E} D$. Bandung: Alfabeta.

Undang-Undang Nomor 20 Tahun 2013 tentang Sistem Pendidikan Nasional. Jakarta: Eka Jaya.

Willson, Brent G. ed. (2006). Constructivist Learning Environment: Case Studies In Instructional Design. New Jersey: Educational Technology Publications, Englewood Cliffs. 